\title{
Study on Variation of Diatoms Flora in Gomati River at Jaunpur for Forensic Consideration
}

\author{
Samiksha Mishra, A .K. Gupta, M. K. Mishra, Vichar Mishra \\ Sam Higginbottom Institute of Agriculture, Technology \& Sciences, Deemed-to-be University, Allahabad \\ ( Deptt. Of Forensic Science, SHIATS, Allahabad. Utter Pradesh, India) \\ (M.Sc.Student, Deptt. Of Forensic Science, SHIATS, Allahabad. Utter Pradesh, India) \\ (Assistant Professor Deptt. Of Forensic Science, SHIATS, Allahabad, Utter Pradesh, India) \\ (PhD. Scholar Deptt. Of Forensic Science, SHIATS, Allahabad. Utter Pradesh)
}

\begin{abstract}
Diatoms are regarded as valuable evidence to correlate the cause of death between drowning or dumping and also for site characterization. They are microscopic unicellular organism, general habitat in aquatic condition, having siliceous cell membrane and they photosynthesize chlorophyll pigments. In present study, 27 water samples were collected from different nine sites of Gomati River at Jaunpur District in the months of December, January and February. The collected water samples were extracted for identification of diatoms after acid digestion and thei sldes were made, according to the arrangement of valve and cell wall shape. On the basis of these examinations, 36 genera identified from different nine sites, in which some genera were common and some genera were specific site in other places the presence of diatom can confirm of river water sample, on the basis of which drowning sites of the dead bodies can be confirm si. It may be valuable for the site characterization by comparison of diatoms between the water sample of drowning site and the viscera of corpse recovered.
\end{abstract}

Keyword: Drowning, Dumping, Microscopic, Unicellular, Organism.

\section{Introduction}

Diatoms are microscopic aquatic unicellular eukaryotic algae having a cell wall made of silica(hydrated silicon dioxide). Diatoms are photosynthetic (autotrophic) algae belonging to the Kingdom Protista and Class Bacillariophyceae. The word 'diatoms' means 'cut in two' and is derived from the Greek word: (dia) = 'through'+ (termine) $=$ 'to cut, i.e. 'cut in half'. In the early twentieth century fossils diatoms were first studied and most famously, Husted (1953), produced a taxonomic and ecological study of diatoms. There are more than 200 genera and approximately 1,00,000 species of diatoms are known Round et al.,(1990). Diatoms constitute major part of the phytoplankton. They are usually yellowish or brownish and are found in fresh water and marine water in moist soil and also on the surface of plants. Diatoms are ranging in size from approximately 5 microns to 1000 microns of the most common type of phytoplankton. All diatoms are enclosed by frustules (cell wall)that are made up of two valves fitted together by a connective zone called a girdle growth occurs by ordinary mitotic cell division as well as through the formation of an exposure by sexual reproduction. Generally it is radically and bilaterally symmetric. They are in many forms including circle, square, triangles, boat shaped and various types of curves.

Diatoms analysis is a valuable tool in forensic science and it is useful in diagnosis of drowning cases. The basic principle of diatoms test in drowning is based on correlation between diatoms are present in the medium where the possible drowning took place. These diatoms are deposited into brain, kidney and other organs by inhalation of water. This vital fact was the key to the investigations as it provided scientific input to know whether the person was dead or alive at the time of drowning. Presence of diatoms in the biological sample serves as an indicator of drowning proving that such organism are present in the submerging medium Krystic et al. (2002).The growth of some species of microorganism is directly related with the temperature, light intensity and physiochemical characteristics of the environment $(\mathrm{pH}$, salinity, the presence of organic matter, etc). Diatoms are formally classified as belonging to the Kingdom - Protista; Division-Chrysophyta; Sub-Division-Algae; Class- Bacillariophyceae. Diatoms have been classified into two orders on the basis of their symmetry: Order 1.Centrales (Biddulphiales): They are pre-dominantly marine water and radially symmetrical. E.g. Cyclotella spp. Order 2.Pennales (Baccillareales): They are pre-dominantly fresh water and usually bear bilaterally symmetry E.g. Pinnularia spp.

\section{Methodology}

\subsection{Collection of water samples}

1 lit. water sample was collected in plastic bottles from each nine ghats Ram Ghat (Sample1), Sooraj Ghat (sample 2), Achala Dev Ghat (sample 3), Shiv Gopal Ghat (sample 4), Viserjan Ghat (sample 5), 
Kirarbeer Ghat (sample 6), BaluaGhat (sample7),Hanuman Ghat (sample 8), Gular Ghat (sample 9) and then bottles were tightly fitted with cap and labelled with location of sampling site, along with date, time, month. Water sample was collected at the Bank, mid, and across the river. Water sample were collected in different month continuously at 25 December, 15 January and 6 February 2015-2016. Water sample were collected from nine different Ghats of Gomati River at Jaunpur District.

\subsection{Extraction of diatom from water samples}

The Collected water samples from various sites of the Gomati River were brought to the laboratory for extraction and isolation of diatom. In water samples add $2-3 \mathrm{ml}$ of $2 \%$ formalin solution to prevent diatom growth .Left it over night or $24 \mathrm{hrs}$ for settlement. Next day discarded the half water without shaking and then shake it very rigorously and poured it in the $500 \mathrm{ml}$ beaker. Added Lugol's Iodine solution 2-4 drops and covered the beaker with brown paper and leftover night. Ludes et al.,(1996).Next day lifted the sediments with the help of dropper and transferred it in the Tarson tube then centrifuged at $1500 \mathrm{rpm}$ for 5-7 minutes and after centrifugation supernatant were discarded. Again two or three times centrifuged water sample to obtained maximum pellets in Tarson tube. In pellets which formed at the bottom of Tarson tube (C.T.) mixed 1-2ml conc. $\mathrm{HNO}_{3}$ and filled tube with distilled water and leave it for 4-6 hrs after that rinse the sample with distilled water 2-3 times and prepare the slide. Tyagi et al., (1885), Pollanen(1998).

\subsection{Microscopic examination}

After washing of pellets amount of it is transferred on the microscopic slide by the help of dropper. These microscopic slide were kept on slide wormer plate at $30-40^{\circ}$ for 5-8 min for drying, then add 1 drop of DPX upon the slides and place the cover slip, slide put in the hot oven for 1 hours. Prepared permanent slide observed under microscope at different magnification such as 10x, 45x, 100x (oil immersion) Taylor et al. (2007) .The same step were repeated for all the samples.

\section{Result And Discussion}

After collection, extraction and isolation of diatoms from different water sample, different diatom were identified by using standard online diatom database of U.S. Their characteristic feature such as raphe, cell , and shapes were examined for their identification.

Diatom genera identified at Ram Ghat:- Achnanthes (Jan. and Feb.), Achananthidium (Feb.), Aneumastus (Feb.), Bacillaria (Dec.), Caloneis (Jan.), Coconeis (Dec.,Jan. ,and Feb.), Cyclotella (Jan. and Feb.) , Cymatopleura (Feb.) , Fragilariforma (Dec.), Gomphonema (Dec.), Nitzschia (Dec. and Feb.), Pinnularia (Jan.), Rhopalodia (Dec.), Stephanocyclus (Jan. and Feb.), Surriella (Feb.), Syendra (Dec.) and Tubularia (Feb.).।

Sooraj Ghat:- Achnanthes (Dec.), Achananthidium (Feb.), Bacillaria ( Dec.,Jan. ,and Feb.), Coconeis ( Dec.,Jan. ,and Feb) , Criticula ( Dec. and Feb.), Cymbella ( Dec. and Jan. ), Cyclotella ( Jan. ,and Feb.), Fallociala ( Dec. and Feb.), Fragilaria ( Dec., Jan.,and Feb.), Geissleria ( Jan.), Nitzschia ( Dec.,Jan. ,and Feb.), Navicula ( Dec. and Feb.), Rhopalodia ( Dec.), Sellphora ( Feb.), Stephanocyclus ( Dec. and Feb.), Surriella (Jan.), Triblionella ( Dec,and Feb.) and Ulnaria ( Dec. and Feb.).

Achala Devi Ghat:- Achnanthes (Jan.), Amphora (Jan.), Aneumastus (Jan.), Aulacoseira (Dec.), Bacillaria (Dec.), Cocconeis (Jan. and Feb.), Criticula (Dec.), Cyclotella (Dec., Jan. and Feb.), Gomphonema (Jan. and Feb.), Melosera (Dec.), Navicula (Dec. and Feb.), Nitzschia (Feb.) and Surriella (Feb.) .

Shiv- Gopal Ghat:- Achnanthes(Jan. and Feb.), Amphora (Dec. and Jan.), Aneumastus (Jan.), Aulacoseira (Jan.), Cocconeis (Dec., Jan. and Feb.), Cyclotella (Dec., Jan. and Feb.), Cymbella (Jan. and Feb.), Cymatopleura (Feb.), Entomoneis (Feb.), Fallociala (Feb.), Fragillariforma (Dec. and Jan.), Geissleria (Dec.), Nitzschia (Feb.), Stephanocyclus (Dec.), Syendra (Jan.), Tribllonella (Jan. and Feb.), and Ulnaria (Feb.).

Viserjan Ghat:- Achnanthes (Feb.), Bacillaria (Dec. and Jan.), Cocconeis (Jan. and Feb.), Cyclotella (Dec. and Feb.), Fragillariforma (Feb.), Melosera (Jan.), Nitzschia (Feb.), Nupela (Jan.), Syendra (Dec.) and Tibularia (Dec.).

Kirarbeer Ghat:- Achnanthidium (Jan.), Bacillaria (Dec.), Cocconeis (Jan and Feb.), Fragilariforma (Dec.), Geisseleria (Dec.), Melosera (Dec.), Nitzschia (Dec., Jan. and Feb.), Nupela (Jan.), Pinnularia (Jan. and Feb.), Stephanocyclus (Jan.) and Surriella (Jan. and Fen.). 
Balua Ghat:- Achnanthes (Jan.), Aneumastus (Jan.), Cocconeis (Jan. and Feb.), Chaetoceros (Feb.), Cyclotella (Jan. and Feb.), Geissleria (Dec.), Pinnularia (Feb.), Sollophora (Jan. and Feb.) and Navicula (Feb.).

Hanuman Ghat:- Achnanthes (Jan.), Aneumastus (Dec.), Amphora (Feb.), Bacillaria (Dec. and Jan.), Cocconeis (Dec., Jan. and Feb.), Cymbella (Jan.), Cyclotella (Jan. and Feb.), Fallaciala (Jan.),Gomphonema (Feb.), Navicula (Dec.), Nitzschia (Dec.), Surriella(Dec.) and Stephanocyclus (Dec. and Jan.).

Gular Ghat:- Achnanthes (Dec.), Bacillaria (Dec.), Cocconeis (Dec., Jan. and Feb.), Cyclotella (Jan. and Feb.), Diatoma (Dec.), Geissleria (Dec.), Nitzschia (Jan) and Stephanocyclus (Dec., Jan. and Feb.).

Table 1 Common diatom species of Gomati River;

\begin{tabular}{|l|l|}
\hline S. No. & Diatom Genera \\
\hline $\mathbf{1}$ & Achnanthes \\
\hline $\mathbf{2}$ & Aneumostus \\
\hline $\mathbf{3}$ & Bacillaria \\
\hline $\mathbf{4}$ & Cocconeis \\
\hline $\mathbf{5}$ & Cyclotella \\
\hline $\mathbf{6}$ & Cymbella \\
\hline $\mathbf{7}$ & Fallaciala \\
\hline $\mathbf{8}$ & Fragillariforma \\
\hline $\mathbf{9}$ & Surriella \\
\hline $\mathbf{1 0}$ & Stephnocyclus \\
\hline $\mathbf{1 1}$ & Syendra \\
\hline $\mathbf{1 2}$ & Nitzschia \\
\hline $\mathbf{1 3}$ & Navicula \\
\hline $\mathbf{1 4}$ & Tribllionella \\
\hline $\mathbf{1 5}$ & Ulnaria \\
\hline
\end{tabular}

In collected water samples from the Gomati River after extraction it was identified under microscope 15 genera of diatoms were identified in Gomati River which were present in each Ghats.

Table 2 Site specific diatom of Gomati River

\begin{tabular}{|l|l|l|l|}
\hline S.No. & Specific diatom genera & Site name & Month \\
\hline $\mathbf{1}$ & Coloneis & Ram Ghat & January \\
\hline $\mathbf{2}$ & Ropolodio & Ram Ghat \& Sooraj Ghat & December \\
\hline $\mathbf{3}$ & Cymatopleura & Ram Ghat & February \\
\hline $\mathbf{4}$ & Melosira & Achala Devi Ghat\&Kirarbeer Ghat & December \& January \\
\hline $\mathbf{5}$ & Entomoneis & Shiv Gopal Ghat & February \\
\hline $\mathbf{6}$ & Nupela & Viserjan Ghat \& Kirarbeer Ghat & January\& February \\
\hline $\mathbf{7}$ & Chaetoceros & BaluaGhat & February \\
\hline
\end{tabular}
and month.

These table shows that 7 specific diatoms genera which were present at specific sites of Gomati River

In this study total number of 36 diatom genera were identified at different nine sites. In which 17 genera were found at Ram Ghat, 18 genera (SoorajGhat), 13 genera (Achala Devi Ghat), 17 genera (shiv Gopal Ghat), 10 genera (Viserjan Ghat), 11 genera (Kirarbeer Ghat), 10 genera (BaluaGhat),14 genera (Hanuman Ghat) and 8 genera (Gular Ghat). In which 15 diatom genera were identified common at all sites .7 genera were identified on specific sites in Gomati River at Jaunpur.

The work performed in this dissertation can be discussed as in accordance with the work performed earlier by the scientist Tiwari et al,.(2006) who reported 20 diatom genera(species) in Allahabad locality, Garima et al..(2013) reported 24 diatoms species in Yamuna River. Different diatoms were identified on the basis of their characteristics features such as Raphea, and Shape were examined for their identification Metzeltin et al., (2005), with the help of this dissertation work we can also identified the site specific diatoms which are present some particular sites. Which can help also in justify to the drowning sites. According to this study scientist also justified the role of diatoms as indicator in drowning and dumping cases.

\section{Conclusion}

From this study it is concluded that the variation in diatom diversity at different sites of Gomati River is very helpful during investigation of the corpse which were obtained from the water bodies. Diatom study can be useful for medico legal purposes such as in unclaimed body related to doubtful drowning and dumping cases.

27 water samples were collected from 9 Ghats of Gomati River at Jaunpur. Out of which 36 genera, 17 genera were found at Ram Ghat, 18 genera (Sooraj Ghat), 13 genera (Achala Devi Ghat), 17 genera (shiv Gopal Ghat), 10 genera (Viserjan Ghat), 11 genera (Kirarbeer Ghat), 10 genera (Balua Ghat), 14 genera (Hanuman 
Ghat) and 8 genera (Gular Ghat). In which 15 diatom genera were identified common at all sites . 7 specific diatom genera were identified on specific site.

The diatom diversity and their distribution were pertinent. The diatom finding from the water sample or biological sample produces a lot of information about the cause of death, locality and probable season.

\section{References}

[1]. Hurlimann, J., Feer, P., Elber, F., Niederberger, K., Dirnhofer, R. and Wyler, D .(2000) Diatom detection in the digestion of death by drowning. Int J Legal Med; 114:6-14.

[2]. Krystic, Svetislav, Aleksej Duma, Bilijana Janevska, Zlatko Levkov, Ksenija Nikolova, and Marina Noveska (2002) Diatom in Forensic Science expertise Of Drowning; A Macedonian Expoertise. Forensic Science International, 127 (3): 198-203.

[3]. Ludes, B., Coste, M., North, N.,Doray, S., Tracqui, A. and Kintz, P. (1999) Diatom analysis in victim's tissues as an indicator of the site drowning. International journal Legal Med. 112:163-166.

[4]. Punia, R.K. (2011) Diatoms: role in drtowning (case report) Journal India Acad Forensic Med. April- June 2011, vol.32,no.2.

[5]. Tiwari, A. and Chauhan, S.V.S. (2006) Seasonal phytoplanktonic diversity of Yamuna .Journal Environmental Biology. 27:35-38.

[6]. Verma, V. (2013)Role of Diatoms in the World of Forensic Science, Verma,J Forensic Res, 4:2.

[7]. Yadav, G., Mishra, M.K., Gupta, A.K. and Shailesh, (2013) Identification of Site Specific Diatom at Yamuna River of Allahabad e-ISSN: 2278-3008,p-ISSN: 2319-7676.Volume 8, Issue 2 (Nov.-Dec. 2013), PP 87-89 (IOSR Journal of Pharmacy and Biological Sciences). 